POLITEKNIK NEGERI NUSA UTARA

\title{
PERTUMBUHAN DAN SINTASAN HIDUP IKAN NILA DENGAN PENAMBAHAN TEPUNG WORI (Ormocarpum cochinchinense) FERMENTASI DALAM PAKAN
}

\author{
Growth And Survival Rate Of Nile Tilapia With Addition \\ Of Wori Powder Fermentation In Feed
}

\author{
Numisye Iske Mose, Jetti Treslah Saselah \\ Program Studi Teknologi Budidaya Ikan, Politeknik Negeri Nusa Utara \\ Email: iskemose88@gmail.com
}

\begin{abstract}
Abstrak: Tanaman wori merupakan salah satu tanaman kelompok fabaceace yang tumbuh melimpah di Sangihe dan sangat potensial digunakan sebagai salah satu sumber pakan ikan. Kadar protein daun wori adalah $25,53 \%$ sehingga berpotensi menjadi protein nabati bagi ikan. Kendala utama yang ditemui ketika memanfaatkan daun tanaman wori adalah kandungan karbohidrat yang tinggi yaitu 48,51\% sehingga dapat mempengaruhi proses pencernaan ikan, penyerapan nutrisi yang berujung pada rendahnya pertumbuhan ikan. Tujuan dari penelitian ini adalah untuk mengetahui pengaruh tepung daun wori femerntasi terhadap laju pertumbuhan spesifik dan sintasan hidup ikan nila. Rancangan percobaan yang digunakan adalah Rancangan Acak Lengkap (RAL). Perlakuan yang dilakukan terdiri dari tiga perlakuan dan tiga kali ulangan yaitu kadar tepung daun wori tanpa fermentasi A (kontrol) 10\%, kemudian B tepung daun wori fermentasi (10\%), dan C tepung daun wori fermentasi (20\%). Laju pertumbuhan spesifik dan efisiensi pakan diuji menggunakan ANOVA sedangkan sintasan hidup akan dianalisis secara deskriptif. Hasil penelitian ini menunjukan bahwa penambahan tepung wori fermenasi dalam pakan dapat meningkatkan nilai laju pertumbuhan spesfik ikan nila dan efisiensi pemanfaatan pakan dengan nilai tertinggi pada perlakuan C yaitu SGR 1,94\%/hari. Sementara itu, untuk semua perlakuan nilai sintasan hidup sebesar $100 \%$.
\end{abstract}

Kata kunci: fermentasi, nila, pertumbuhan, sintasan hidup, wori

\begin{abstract}
The wori plant is one of the plants of the fabaceace group that grows abundantly in Sangihe and has potential to be used as a source of fish feed. The protein content of wori leaves is $25.53 \%$, so it has the potential to become vegetable protein for fish. The main obstacle encountered when utilizing wori plant leaves is the high carbohydrate content of $48.51 \%$ so that it can affect the digestion process of fish, nutrient absorption which lead to low fish growth. The purpose of this study was to determine the effect of wori femerntation leaf meal on the specific growth rate and survival of tilapia. The experimental design used was a completely randomized design (CRD). The treatments consisted of three treatments and three replications, namely the content of fermented wori leaf powder, A (control) 10\%, then B fermented wori leaf powder (10\%), and C fermented wori leaf powder (20\%). Specific growth rate and feed efficiency were tested using ANOVA, while survival rate was analyzed descriptively. The results of this study indicate that the addition of fermented wori powder in the feed can increase the value of the specific growth rate of tilapia and feed utilization efficiency with the highest value in treatment C, namely SGR $1.94 \%$ / day. Meanwhile, for all treatments the survival rate was $100 \%$.
\end{abstract}

Keyword: fermentation, growth, nile tilapia, survival rate, wori 


\section{PENDAHULUAN}

Penyediaan pakan dengan kualitas dan kuantitas yang baik dapat menentukan keberhasilan suatu kegiatan budidaya ikan. Hal ini disebabkan pakan merupakan unsur utama dalam pertumbuhan ikan. Kualitas pakan dipengaruhi oleh kandungan protein dan asama amino yang terkandung dalamnya dimana hal tersebut tidak hanya mempengaruhi pertumbuhan akan tetapi dapat mengganti sel atau jaringan yang rusak maupun untuk perawatan tubuh (Rambo et al., 2018).

Pakan buatan dalam bentuk pelet sangat disukai oleh ikan namun harga pelet sangat mahal sehingga memberatkan bagi para pembudidaya. Oleh karena itu, pelet tersebut harus disubtitusi dengan bahan lokal yang lebih murah namun berkualitas. Biaya produksi untuk pakan ikan berkisar antara $60-70 \%$. Solusi yang dapat dilakukan adalah dengan menekan biaya produksi sehingga perlu membuat pakan buataan dengan memanfaatkan sumber bahan baku lokal (Akbar et al., 2014; Winarti et al., 2017), seperti tanaman wori.

Tanaman wori merupakan salah satu tanaman kelompok fabaceace yang tumbuh melimpah di Sangihe dan sangat potensial digunakan sebagai salah satu sumber pakan ikan. Hal ini didasari oleh pertimbangan membudidayakan tanaman wori sangat mudah sehingga ketersediaanya terjamin dan harga jual dipasar masih terjangkau. Penelitian sebelumnya yang telah dilakukan menyebutkan kadar protein daun wori adalah $25,53 \%$ sehingga berpotensi menjadi protein nabati bagi ikan. Salah satu contohnya dapat diterapkan pada ikan nila. Ikan nila merupakan ikan omnivora yang menyukai pakan jenis apapun. Kebutuhan protein dalam pakan berkisar 27-35\%. Ikan nila memiliki pertumbuhannya juga cepat, mudah untuk dibudidayakan, memiliki nilai ekonomis, serta disukai oleh masyarakat umum.

Namun demikian, dalam pengembangan bagian daun tanaman wori terkendala dengan tingginya kandungan karbohidrat dalam tanaman ini. Kandungan karbohidrat daun tanaman wori berkisar $48,51 \%$. Ikan memiliki keterbatasan dalam mengelola karbohidrat sebagai sumber energi. Apabila kandungan energi non-protein pakan berlebih seperti karbohidrat dan lemak, maka kandungan energi pakan menjadi tinggi. Hal tersebut akan membatasi jumlah pakan yang dikonsumsi oleh ikan sehingga jumlah protein pakan pun terbatasi. Pakan yang mengandung karbohidrat yang terlalu tinggi dapat menyebabkan menurunnya nilai kecernaan protein serta akan menurunkan pertumbuhan ikan (Hadadi, 2002).

Fermentasi adalah proses perubahan kimia yang menguntungkan karena makanan yang difermentasi akan lebih lunak, harum dan rasanya berbeda. Dalam proses fermentasi menggunakan mikrobia tertentu, bahan yang diuraikan karbohidrat, tidak menimbulkan bau busuk dan dalam kondisi terkontrol (Cici et al., 2019).

Berdasarkan uraian sebelumnya, penelitian ini bertujuan untuk mengetahui pengaruh penambahan tepung daun wori fermentasi ke dalam pakan buatan terhadap pertumbuhan dan sintasan hidup ikan nila.

\section{METODE}

Penelitian dilaksanakan di Pusat Budidaya Ikan Air Tawar Politeknik Negeri Nusa Utara di Kampung Siha, Kecamatan Mangaitu, Kabupaten Kepulauan Sangihe selama bulan Juli sampai September 2020.

\section{Alat dan Bahan Penelitian}

Bahan yang digunakan dalam penelitian ini adalah ikan nila, daun wori, bungkil kelapa, tepung jagung, dedak halus, tepung ikan, larutan fermentasi, 
dan tepung sagu. Sedangkan alat yang digunakan dalam penelitian ini adalah alat pencetak pelet, blender, ayakan, dan toples.

\section{Rancangan Penelitian}

Penelitian ini menggunakan Rancangan Acak Lengkap (RAL) yang terdiri dari 3 perlakuan dan 3 ulangan. Perlakuan yang diberikan yaitu :

Perlakuan A : Pakan dengan Penambahan Tepung Daun Wori

Perlakuan B : Pakan dengan Penambahan Tepung Daun Wori Fermentasi 10\%

Perlakuan C : Pakan dengan Penamabahan Tepung Daun Wori Fermentasi 20\%

\section{Prosedur Penelitian}

\section{Pembuatan tepung wori terfermentasi}

Daun wori yang telah dipetik dicuci dan keringkan di bawah sinar matahari. Daun wori yang telah kering kemudian diblender untuk memperoleh tekstur yang halus. Tepung daun wori kemudian dicampur dengan larutan fermentasi (Rostika et al., 2017). Larutan fermentasi dibuat dengan cara mengencerkan EM-4 dalam air dengan ratio 10:1000 kemudian diberi gula sebanyak 1 sendok dan didiamkan selama 24 jam. Larutan EM-4 yang digunakan Lactobacillus casei, Saccharomyces cerevisiae, dan Rhodopseudomonas palustris yang diproduksi oleh PT. Songgolangit Persada. Setelah 24 jam, larutan tersebut kemudian dicampurkan dengan tepung daun wori dengan rasio 3:10. Campuran tersebut kemudian disimpan dalam plastik pada suhu $29^{\circ} \mathrm{C}$ dengan kondisi aerob selama 3 hari.

\section{Pembuatan Pakan Buatan}

Pakan dibuat berdasarkan formulasi protein

$30 \%$. Untuk formulasi pakan dihitung menggunakan metode bujur sangkar. Bahan baku untuk pembuatan pakan buatan antara lain tepung ikan, bungkil kelapa, tepung jagung, dedak halus, vitamin dan sagu. Adapun formulasi pakan yang digunakan sebagai berikut:

Tabel 1. Formulasi Pakan Buatan

\begin{tabular}{|l|l|l|l|}
\hline \multirow{2}{*}{$\begin{array}{l}\text { Bahan baku } \\
\text { Pakan }\end{array}$} & \multicolumn{3}{|c|}{ Jumlah Bahan } \\
\cline { 2 - 4 } & \multicolumn{1}{|c|}{0} & \multicolumn{1}{|c|}{$10 \%$} & \multicolumn{1}{|c|}{$20 \%$} \\
\hline Tepung ikan & 264,4 & 264,4 & 264,4 \\
\hline $\begin{array}{l}\text { Bungkil } \\
\text { kelapa }\end{array}$ & 264,4 & 264,4 & 264,4 \\
\hline $\begin{array}{l}\text { Tepung } \\
\text { Jagung }\end{array}$ & 195,6 & 195,6 & 195,6 \\
\hline Dedak Halus & 195,6 & 195,6 & 195,6 \\
\hline Vitamin & 1,5 & 1,5 & 1,5 \\
\hline Sagu & 38,5 & 38,5 & 38,5 \\
\hline $\begin{array}{l}\text { Tepung daun } \\
\text { wori } \\
\text { fermentasi }\end{array}$ & 0 & 100 & 200 \\
\hline
\end{tabular}

\section{Pemeliharaan ikan}

Ikan nila dimasukkan ke dalam sembilan buah hapa berukuran masing-masing $1 \times 1 \times 1,25 \mathrm{~m}$ dengan kepadatan 50 ekor per hapa. Sebelum ikan diberi perlakuan ikan diaklimatisasi terlebih dahulu selama 1 minggu. Selama proses aklimatisasi ikan diberi pakan pellet komersil. Dosis pakan yang diberikan sampai ikan tidak merespon lagi terhadap pakan dan diberikan dua kali sehari yaitu pagi jam 08.00 dan sore jam 16.00. Ikan nila dipelihara selama empat minggu.

\section{Pengambilan Data}

\section{Pengamatan pertumbuhan dan Sintasan Hidup}

Pengambilan data dilakukan setiap minggu sekali yaitu pada hari ke 0, 7 14, dan 28. Parameter pertumbuhan yang diamati yaitu

Laju Pertumbuhan Spesifik :

$S G R=\left(\frac{\ln W_{t}-\ln W_{0}}{t}\right) \times 100$

Keterangan :

SGR = Laju pertumbuhan spesifik $(\%)$ 
$\mathrm{W}_{\mathrm{t}} \quad=$ Berat ikan pada akhir pemeliharaan $(\mathrm{g})$

$\mathrm{W}_{0} \quad=$ Berat ikan pada awal pemeliharaan $(\mathrm{g})$

$\mathrm{t}=$ Waktu pemeliharaan (hari)

Sintasan Hidup

Sintasan Hidup (SR) dihitung menggunakan rumus (Effendie, 1997) yaitu :

$S R=\frac{N_{t}}{N_{0}} \times 100$

Keterangan :

SR $=$ Sintasan hidup ikan $(\%)$

$\mathrm{N}_{\mathrm{t}}=$ Jumlah ikan pada akhir pemeliharaan

$\mathrm{N}_{0} \quad=$ Jumlah ikan pada awal pemeliharaan

\section{Pengukuran kualitas air}

Pengukuran kualitas air dilakuan setiap minggu sekali dan parameter yang diukur adalah suhu dan $\mathrm{pH}$.

Analisis Data
Analisis data untuk laju pertumbuhan spesifik menggunakan ANOVA, untuk sintasan hidup ikan nila akan dijelaskan secara deskriptif.

\section{HASIL DAN PEMBAHASAN}

\section{Laju Pertumbuhan Spesifik}

Laju pertumbuhan merupakan penambahan jumlah bobot atau panjang ikan dalam periode waktu tertentu. Pertumbuhan pada ikan dipengaruhi oleh faktor eksternal dan internal dalam tubuh ikan. Selain dipengaruhi oleh lingkungan perairan, salah satu faktor eksternal yang cukup berpengaruh terhadap pertumbuhan ikan adalah pakan (Rambo dkk., 2018). Pakan yang baik harus memiliki kualitas yang unggul dan kandungan nutrisi yang sesuai dengan kebutuhan ikan.

Hasil pengamatan laju pertumbuhan spesifik terhadap ikan nila memberikan hasil yang berbeda dari masing-masing perlakuan selama 28 hari pemeliharaan.

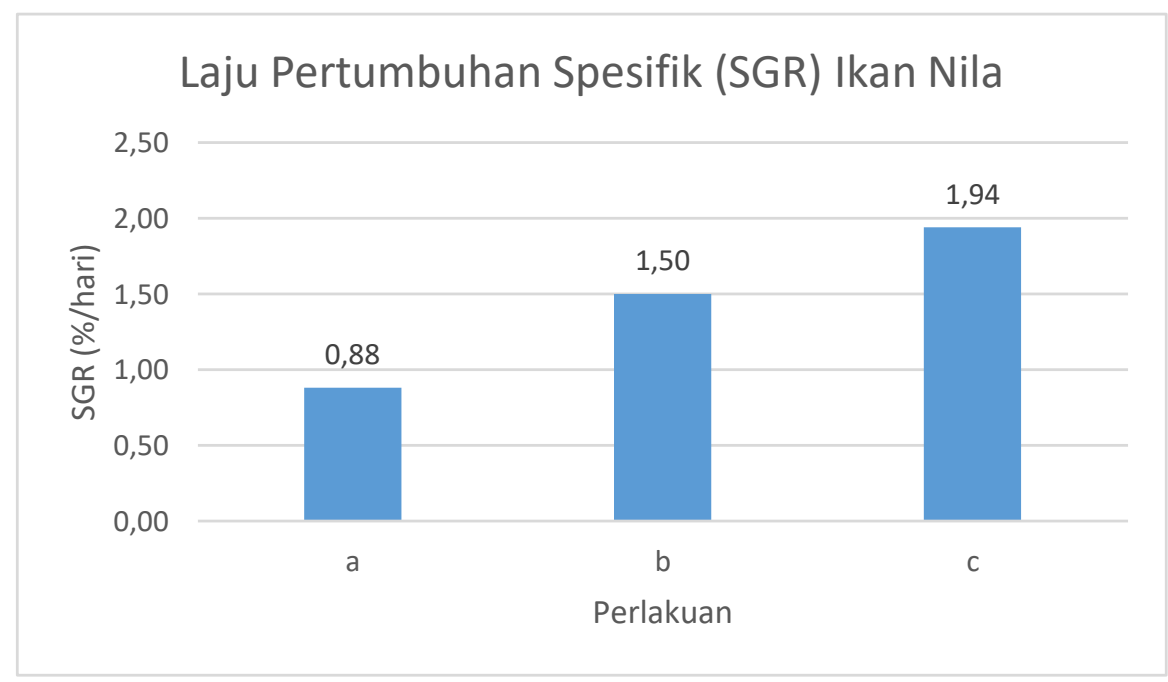

Gambar 1. Laju Pertumbuhan Spesifik Ikan Nila pada Berbagai Perlakuan

Nilai laju pertumbuhan spesifik tertinggi pada perlakuan C sebesar 1,94\%/hari dan nilai laju pertumbuhan spesifik terendah pada perlakuan A sebesar $0,88 \%$ /hari. Hasil penelitian menunjukkan bahwa semakin tinggi dosis tepung wori fermentansi nilai laju pertumbuhan spesifik cenderung naik. Hal ini kemungkinan disebabkan oleh tepung daun wori yang telah difermentasi baik pada perlakuan B dan C dapat meningkatkan kandungan protein dan karbohidrat pada pakan sehingga dapat 
dimanfaatkan sebagai sumber nutrisi untuk menunjang pertumbuhan ikan. Menurut Rosmawati (2005) dalam Handayani dkk., (2017) dikatakan karbohidrat yang cukup akan mencegah penggunaan protein untuk energi sehingga protein yang ada akan dimanfaatkan untuk pertumbuhan.

Perlakuan C (penambahan tepung wori fermentasi 20\%) memberikan nilai laju pertumbuhan spesifik tertinggi. Hal ini kemungkinan disebabkan dalam pakan buatan ini penggunaan tepung wori yang digunakan cukup baik dan ditunjang dengan komposisi bahan pakan lainnya. Seperti yang dikemukakan oleh Afrianto dan Liviawaty (2005) dikatakan untuk mencapai keseimbangan nutrisi dalam pakan ikan maka penggunaan sumber pakan nabati dan hewani dan dilakukan secara bersama-sama.

Hasil penelitian ini juga menunjukkan bahwa nilai laju pertumbuhan dari semua perlakuan sebesar 0,88-1,94\%/hari (Gambar 1). Nilai laju pertumbuhan pada penelitian ini cenderung lebih tinggi jika dibandingkan hasil penelitian (Rachmawaty dkk., 2006) yang memperoleh laju pertumbuhan $0,8-1,6 \% /$ hari yang menggunakan EM-4 pada pakan untuk pertumbuhan ikan nila merah.

\section{Sintasan Hidup}

Berdasarkan hasil pengamatan, sintasan hidup ikan nila yang diberi pakan dengan penambahan daun wori pada berbagai konsentrasi tersaji pada Gambar 2.

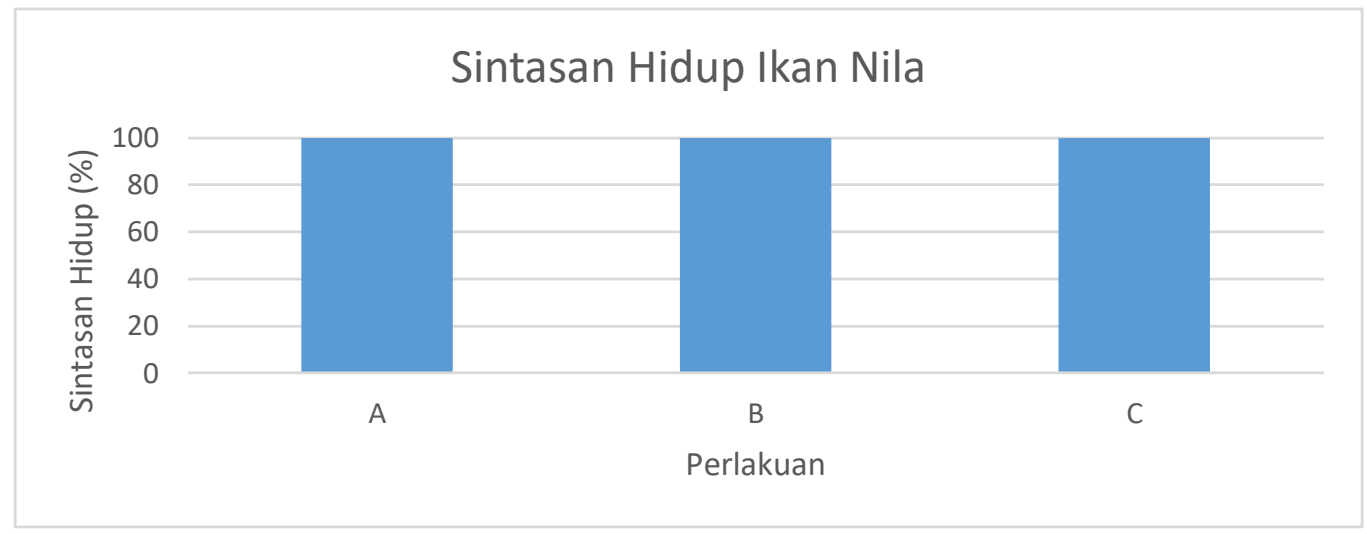

Gambar 2. Sintasan Hidup Ikan Nila pada Berbagai Perlakuan

Gambar 2 menunjukkan bahwa penambahan daun wori pada pakan untuk ikan nila menunjukkan nilai sintasan hidup sebesar $100 \%$. Hal ini diduga bahwa pakan dengan penambahan tepung wori fermentasi hanya berpengaruh terhadap pertumbuhan tetapi tidak berpengaruh terhadap sintasan hidup ikan.

Kelangsungan hidup atau sintasan hidup merupakan persentase nilai yang menyatakan jumlah ikan yang hidup selama waktu pemeliharaan dibagi dengan jumlah ikan yang ditebar (Effendi, 1997). Faktor kualitas dan kuantitas pakan serta kualitas lingkungan akan menentukan nilai sintasan hidup ikan. Sementara itu, apabila lingkungan hidup tidak baik dan faktor pakan makanan tidak menunjang maka dapat menyebabkan ikan stress yang berujung pada mortalitas ikan (Cici et al., 2019).

\section{Kualitas Air}

Faktor penting yang harus diperhatikan dalam pemeliharaan ikan adalah kualitas air karena mempengaruhi kelangsungan hidup dan dapat menyebabkan penyakit. Kualitas air yang mulai 
memburuk akan membuat ikan mengalami stress sehingga lebih mudah terserang penyakit dan jika tidak segera ditangani akan menyebabkan kematian ikan (Cici et al., 2019).

Hasil pengukuran kualitas air selama penelitian memiliki nilai kelayakan dalam batas yang optimal. Suhu selama penelitian menujukkan nilai sebesar $27-29^{\circ \mathrm{C}}$. Sementara itu, nilai $\mathrm{pH}$ yang diukur selama penelitian menujukkan hasil 8. Besar atau kecilnya $\mathrm{pH}$ akan mempengaruhi proses biokimiawi pada ikan (Virnanto et al., 2016). Nilai $\mathrm{pH}$ dan suhu kualitas air telah sesuai berdasarkan SNI 6141.

\section{KESIMPULAN}

Ikan nila yang diberi penambahan tepung daun wori fermentasi sebanyak $20 \%$ dalam pakan menujukkan nilai pertumbuhan yang terbaik dibanding dengan perlakuan lainnya. Nilai laju pertumbuhan spesifik sebesar 1,94\%/hari. Sementara itu, untuk sintasan hidup semua perlakuan menunjukan nilai $100 \%$.

\section{DAFTAR RUJUKAN}

Afrianto. E dan Liviawaty. E. 2005. Pakan Ikan (Pembuatan, Penyimpanan, Pengujian, Pengembangan). Yogyakarta: Kanisius.

Akbar, C. Sukanto, Rukayah, S. 2014. Kualitas Pakan Fermentatif Berbahan Kulit Ubi Kayu Dengan Inokulan MEP + Untuk Kultur Ikan Nila GESIT (Oreochromis niloticus). Scripta Biologika 1(2):141-145.

Cici, M. Yanto, H. Lestari, T.P. 2019. Pengaruh Penambahan Dedak Halus Yang Difermentasi Dengan Saccharomyces cerevisiae Dalam Pakan Terhadap Pertumbuhan Ikan Biawan (Helostoma temminckii). Borneo Akuatika 1(2): 95103.

Effendie, M.I. 1997. Biologi Perikanan. Yogyakarta: Yayasan Pustaka Nusatama.
Hadadi, A. 2002. Pengaruh Kadar Karbohidrat Pakan Berbeda Terhadap Pertumbuhan dan Efisiensi Pakan Ikan Gurame (Osphronemus gouramy Lacepede) Ukuran 70-80 g. Tesis. Program Pascasarjana Institut Pertanian Bogor.

Handayani, T. Susilowati, T. Subandiyono. 2017. Pemanfaatan Tepung Daun Lamtoro (Leucaena Leucocephala) Yang Difermentasi Dalam Pakan Buatan Untuk Pertumbuhan Benih Ikan Mas (Cyprinus carpio). Journal of Aquaculture Management and Technology 6(4):226335 .

Rachmawaty, F. Susilo, U. Hariyadi, B. 2006. Penggunaan Em4 Dalam Pakan Buatan Untuk Meningkatkan Keefisienan Pakan Dan Pertumbuhan Ikan Nila Gift (Oreochromis Sp.). J.Agroland 13 (3) : 270 -274 .

Rambo, Yustiati, A. Dhahiyat, Y. Rostika, R. 2018. Pengaruh Penambahan Tepung Biji Turi Hasil Fermentasi Pada Pakan Komersial Terhadap Pertumbuhan Dan Kelangsungan Hidup Ikan Nila (Oreochromis Niloticus). Jurnal Perikanan Dan Kelautan Ix(1):95-103.

Rostika R., Andriani Y., Henry A., Vinasyiam, A. 2017. Laju pertumbuhan benih ikan nila (Oreochromis niloticus) yang diberi pakan mengandung tepung lemna terfermentasi. Jurnal Akuakultur Indonesia 16(1):101106.

SNI 6141. 2009. Produksi Benih Ikan Nila Hitam (Oreochromis niloticus Bleeker) Kelas Benih Sebar.

Virnanto, L. Rachmawati, D. Samidjan,I. 2016. Pemanfaatan Tepung Fermentasi Azolla (Azolla Microphylla) Sebagai Campuran Pakan Buatan Untuk Meningkatkan Pertumbuhan Dan Kelulushidupan Ikan Gurame (Osphronemus Gouramy). Journal of Aquaculture Management and Technology 5(1):1-7.

Winarti, Subandiyono, Agung S. 2017. Pemanfaatan Fermentasi Tepung Lemna sp. Dalam Pakan Buatan Terhadap Pertumbuhan Ikan Mas (Cyprinus carpio). Jurnal Sains Teknologi Akuakultur 1(2): 88-94. 